\title{
Music and Tourism: Their Roles in Generating Employment in Nigeria
}

\author{
SUNDAY N. NNAMANI* \\ Faculty of Humanities and Social Sciences, Federal University Ndufu-Alike Ikwo, Pmb 1010 Abakaliki, Ebonyi State, Nigeria \\ *Corresponding author: sundaynnamani2010@yahoo.com
}

Received October 28, 2014; Revised November 10, 2014; Accepted November 17, 2014

\begin{abstract}
Apart from education, culture is another factor on the wheel of development of any nation. A society is distinguished from another as a result of culture. Culture constitutes the totality of customs, rituals, music, food, patterns of building houses, norms and values that regulate the people's way of life. Music, festivals and tourist centres are part of culture. This paper examines the role of music in festivals in Nigeria. It noted that specifically that during festivals people travel from far and near, play vital roles in the celebrations as it serves as an important source of information. Festivals are integral parts of tourism. It further examined the extent of development of tourism in Nigeria, types of tourism, investment opportunities available and mentioned some of the tourist sites. Their roles in generating employment were enumerated emphasizing that as labour-intensive industries, they have the potential to create more jobs per unit of investment. There is a conclusion and recommendation urging governments to make investments on music, culture and tourism top priorities in their development agendas.
\end{abstract}

Keywords: music, culture, investment, tourism

Cite This Article: SUNDAY N. NNAMANI, "Music and Tourism: Their Roles in Generating Employment in Nigeria." American Journal of Educational Research, vol. 2, no. 11 (2014): 1065-1068. doi: 10.12691/education-2-11-10.

\section{Introduction}

Music is the most widely practised of all the arts in Nigeria. At any time of the night or day, somewhere in the land or sea, some type of music is practiced (Okafor 2009). Cardinal to this type of music is its integral relationship to the life, life styles and patterns of the individuals within the communities and the wider societies.

The relationship, similarity or differences between the music of these communities depend on the relationship between their languages and culture. Culture is the actual determinant of the type of music to be performed and it is called traditional or folk music. Traditional music in Nigeria (all tribes inclusive) has a close relationship with other forms of art such as crafts, drama, painting, dances, gestures, songs, instrumental renditions, sculpture and oral poetry. It is also functional-associated with a particular festival or event.

Tourism on its own is defined as any activity that involves the movement of people from their normal place of residence and work to another destination. This may be for a period not less than 24 hours and not more than one consecutive year.

The purpose of this tour may be for sporting activities, leisure, recreation or religious purposes.

Essentially, tourism can have a profound impact on the society, economy and the environment of different societies and nations.

\section{Music in the Traditional Society}

Traditional music in Nigeria is functional, that is; they are used for performing certain functions within the society. When they are intended to be used for social, ceremonial, religious and economic purposes, everyone present, that is; the audience is involved. But when it is for the purpose $s$ of ritual, the people involved are selected. This is because they are certain activities associated with that music which is termed as taboos and the un-initiated and women for example are not permitted to participate. This is in a close circuit involving secret things which are performed usually in the night.

The musician has a role as a keeper of public conscience and as a man that controls the society. He guides the society, foresees events like the poet and also draws from the collective wisdom and pool of knowledge of the people. The musician therefore, has an acceptable role in many of our traditional societies.

He has a role, a place, rights and privileges as a full member of the society. Supporting this, Merriam (1964:136) earlier on said that;

Life in a village without musicians is not to be considered, and people spoke of leaving the village wee no musicians are present...

The fact of the matter is that without musicians, a village is incomplete; people want to sing and dance and a number of important village activities cannot be carried out without musicians. 


\section{Festivals in Nigeria}

African (Nigerian) communities organize and celebrate different types of festivals. By definition, festivals are events that are based on a group communion that manifests the communal behavioural patterns. It is an occasion during which members of a society demonstrates their ingenuities in dancing, singing and artistic designs. Festivals ordinarily mean fiesta, celebration, merry making or performances. It involves all forms of sports, wrestling contest and musical concerts.

In Africa and Nigeria in particular, festivals are organized around major events such as episodes from the history of an ethnic group, agricultural yields, coronation of the natural rulers, natural phenomena such as the rivers, forest reptiles and other officially recognized deities. Commenting on this, Ehiwario (2005:89) said;

Festivals are also held to celebrate significant landmarks that had occurred in the history of a people. In other words, some festivals are rooted in the historical antecedents of a people. Some festivals are associated with the purification rites.

...And man has constantly observed this trend of happenings and at the same time take special note of them by organizing a kind of festival to appreciate such forces behind the seasonal happenings.

In his article "Festac in Retrospect” Ogbechie (1988:4) observed that "festivals ensure adequate and consistent revival and allow a nation evaluate the trend of its cultural developmental and growth”. On his own part Ogbu (1990:2) noted that the social and moral life in African traditional society is evaluated during festival celebrations. This is because during festivals, people travel from far and near, play vital roles in rhe celebrations as it serves as an important source of information. Happenings within the village are revealed in the people's folk music thereby controlling the moral and social behavior of the citizens. Festivals are integral parts of tourism.

Some of the major Nigerian festivals that can be included as tourist centres are; the Mmanwu Festivals for the Igbo, the Durbar Festival of the Kanuri, Eleghe Royal Festival of Okere town in Warri, Ikeji-Arochukwu New Yam Festival, the Igue Festival of Benin, Argungu Fishing Festival of Kebbi, Egwu-Ogba Festival of Egi, Rivers state, the Ekpo Masquerade Festival of Akwa Ibom state, the Ofala Festival of Onitsha and the Osun Osogbo Festival, which was in 2005 officially granted the UNESCO recognition award for World Heritage Sites.

(TOTAL ELF Petroleum Nigeria Limited, 2006).

\section{Tourism in Nigeria}

Nigeria offers a wide variety of tourist attractions such as extended and roomy river and ocean beaches ideal for swimming. Others include, water sports, unique wildlife, vast tracts of unspoiled nature ranging from tropical forest and magnificent waterfalls. There are some new rapidly growing cities and climatic conditions in some parts of the country particularly conducive for holidaying.

Other attractions include traditional ways of life preserved in local customs, rich and varied handicrafts and other colourful products illustrative of native arts and lifestyle and "the authentic unsophisticated but friendly altitude of many in the Nigerian population”. (http://www.onlinenigeria.com4:1:2014).

However, many of these attractions are still largely untapped and even at their raw states. They are still being enjoyed by few outsiders, either by few visitors in quest of exoticism or adventure and in search of new challenges and experiences. The lack of the required modern infrastructural facilities and in some parts of the country acute conditions of underdevelopment and poverty can be seen which many potential Nigeria bound tourist may not like to be confronted with.

\section{Divisions of Tourism}

The rapid growth of the modern tourism industry which in 2005 registered approximately 800 million international tourist arrivals worldwide has made the tourism industry one of the most important industries of the world especially in economic terms. One of the most valuable characteristics of the industry is that while it has grown in numbers, it has also grown in variety of destinations as there has been a continued geographical spread of tourism to all parts of the world which has made it possible for many countries especially the developing ones, to develop it as a viable engine for socio-economic development (Frangialli, 2006).

The types include;

a). Adventurous sites - discovered caves, the unknown forests.

b). Site attractions found in the states.

c). Eco-tourism - ecological sites, green environment, animals, vegetation, wildlife, parks.

d). Religious tourism - Haij, Christian pilgrimage, Retreat centres.

e). Gastronomy tourism - for example, a white man leaving his country to come to Nigeria to taste the local food.

f). Transport tourism - Land, air and sea.

g). Cultural tourism - music, dance, drama and folklore.

h). Hospitality tourism - Hotels and relaxation centres.

\section{Tourism Investment Opportunities in Nigeria}

A tourism policy was produced in 1990 with the basic objectives to make Nigeria the ultimate tourism destination in Africa. The main trust of this government's policy is to generate foreign exchange, encourage even development, promote tourism based rural enterprises, generate employment and accelerate rural urban integration and cultural exchange. Such opportunities exist in the areas of favourable investment climate, tour operations, tourism incentives, provision of basic infrastructural facilities, concession on lands and finally patrol and regulation of the industry. Some of the tourist centres in Nigeria are, Yankari Game Reserve, Mambilla Plateau, Gashaka-Gumti National Park, Cross River National Park, The Kainji National Park, Coconut Beach, Lagos Bar Beach, Tarkwa Bay, Calabar Beach, Lekki Beach, Eleko Beach, Obudu Cattle Ranch etc.

Concluding, tourism investment atmosphere in Nigeria is now conducive given the abundant resources available, large market, enthronement of enduring democracy and a 
package of incentives put together by the government in power. Foreign investors and other interested individuals should therefore take these advantages to invest in the Nigerian tourism industry for sustainability and profitable returns.

\section{Challenges to Tourism Development In Nigeria}

One of the most important challenges facing the modern world is the fight against poverty ad this is a battle that governments, agencies and institutions have been fighting over the years. There are impediments to our tourism industry which the present administration. These include the development of;

- Heritage/cultural tourism resources, development of slave trade relics.

- Establishment of museums and preservation of monuments.

- Wildlife tourism resources.

- Development of picnic and camping sites at strategic locations within the trait circuit system in the national parks.

- Building of reception centres at natural physical attractions

- Establishment of hotels and resorts near waterfalls, springs, caves and temperate climate areas such as Obudu, Jos and Mambila Plateau.

- Development of arts and crafts which constitute symbol of the people's cultural values and love for nature. (http://www.onlinenigeria.com4:1:2014)

When these had been achieved, it will assure the success and sustainability of Nigeria tourism industry.

\section{Roles in Generating Employment}

Since music is an easily digestible medium of communication, it is the most effective medium of cultural export resulting in economic benefit. Here it involves the processing and distribution of music in a material form or making use of music that had already been placed in material form. All these can be translated into economic benefits that generates employment. Anuforom (1984) rightly observed that music has as one of its objectives "the development of the child's talent, physical skills as well as the acquisition of specific vocational training that could enable one develop healthy attitude towards honest labour”. The acquisition of these skills are essential ingredient for the building of a self-reliant individual capable of employing himself.

There are many ways through which education in music can make one self-reliant thereby minimizing the problem of unemployment in Nigeria. According to Nnamani (2009) these include;

1. The establishment of personal music studies for music productions. By this, the graduate becomes a producer, arranger or music director.

2. He can also establish a music band, thereby engaging in musical performances to earn a living. Many renowned musicians within and outside Nigeria have succeeded in life through private ownership of bands.
3. One can become self-employed by engaging in the coaching and grooming of church choirs and orchestra.

4. Unemployment can be curbed through the establishment of school of music and also becoming a music promoter.

5. Through the knowledge of music education, one can become an instrument or music technologist thus engaging in the designing, fabrication, repairs and maintenance of musical instruments.

Essentially, tourism can have a profound impact on the society, economy and environment of nations. Socially, one of the most immediate benefits of the tourism industry is its ability to create employment both skilled and unskilled labour. As a labour-intensive industry, tourism has the potential to create more jobs per unit of investment than any other industry and tourism can be a useful source of employment for women and ethnic minority groups.

Environmentally, tourism when properly developed and managed, can serve as a mechanism for protecting natural environments; preserving historical, archaeological and religious monuments stimulating the practice of local cultures, folklore traditions, arts and crafts and cusine.

Economically, tourism brings many benefits to the federal government, local authorities as well as the private sector through the generation of foreign revenue, financial returns on investment, taxation on tourists and tourists' products and linkages to other local industries such as agriculture and fisheries.

Quoting Frangialli (2006)

Nigeria is one of the leading countries in Africa in the fight against poverty and plays an active role in United Nation's World Tourism Organization's ST-EP programme (Sustainable Tourism-Eliminating Poverty) - a programme which was launched in 2002 and focuses on longstanding work to encourage sustainable tourism-social, economic and ecological- which specifically alleviates poverty bringing development and jobs to people living on less than a dollar a day.

\section{Conclusion}

The writer is convinced that with the enormous economic power, and high potential for employment generation of music and tourism and with its capacity of spreading its socio-economic benefits to all levels of the society, both can be leading sectors in the fight against poverty.

\section{Recommendation}

In this era when globalization has enormous impact and greater number of world economies are depending largely on music, culture and tourism, investments on these areas should be made top priorities in their development agendas.

\section{References}

[1] Anuforom, H.U. (1984). The Role of Music Traditional Education in Conference of Music Educators, A.I.C.E. Owerri. 
[2] Ehiworio, M.O. (2005) Message by the Secretary General of the World Tourism organization. Nigeria Tourism Developmental Master Plan http://www.onlinenigeria.com(2014). Tourism in Nigeria assessed $4^{\text {th }}$ January.

[3] Merriam, A.P. (1964). The Anthropology of Music. Evanston: Northwestern University Press.

[4] Nnamani, S.N. (2009). Teaching Music n Nigerian Schools. A practical Approach. Enugu: Providence Press Nig. Ltd.

[5] Ogbuchie, O. (1988). Festac in Retrospect. Nigeria Observer, Tuesday $7^{\text {th }}$ March. Benin-city: page 10 .
[6] Ogbu, G.O. (2000). The Role of Music in Festival. An Unpublished N.C.E. Research Work. College of Education, Agbor

[7] Okafor, R.C. and Okafor, C.U. (2009). Music and National Development in Nigeria. Enugu: New Generation Books.

[8] TOTAL ELF Petroleum Nigeria Limited (2006). Nigerian Festivals. Abuja: Total Elf Petroleum Nig. Ltd. 